\title{
Recommended and experimental values of the earth surface shift troughs parameters when conducting the stope works
}

\author{
Mykhailo Filatiev ${ }^{1 *}$, and Elvira Filatieva ${ }^{2}$ \\ ${ }^{1}$ Donbas State Technical University, Mining Department, 84 Peremohy Ave., 93100 Lysychansk, \\ Ukraine \\ ${ }^{2}$ Donbas State Technical University, Department of Ecology, Life Safety and Labor Protection, \\ 84 Peremohy Ave., 93100 Lysychansk, Ukraine
}

\begin{abstract}
The correspondence of angular and linear parameters of the undermined rocks displacement and the crustal movement to their values determined according to the normative document has been established. Based on the surveying observations over the reference points movement on the earth surface and the stope face advance, the empirical curve of the trajectory of the earth surface maximum subsidence is determined from the points of maximum subsidence. The curve of the maximum subsidence of the earth surface points when removing the stope face from the face entry has been experimentally established, which allowed to determine the location of the point of the beginning of the crustal movement and the dimension of the stope mine working corresponding to this situation. The coordinates of the characteristic points of the earth surface subsidence above the stope face have been determined. A unified method has been developed for determining the angular and linear parameters of the undermined rocks displacement for the two stages of shift troughs formation on the earth surface. The nonconformities have been established between the recommended parameters and the experimental data normative documents during the anthracite seams mining.
\end{abstract}

\section{Introduction}

At present time there is no general computational scheme of the link between the parameters of the crustal movement and the undermined rocks in the normative document [1]. The determination of the degree of the recommended parameters compliance with their experimental values is an important task. When considering the impact of coal seams mining on the earth surface, the two stages of shift troughs formation, conditionally independent among themselves, are taken into account. The first is connected with the beginning of the stope works and their development till the formation of the shift trough flat bottom. The second stage is after the flat bottom formation (complete undermining). The general computational scheme for determining the angular and linear parameters of rocks displacement and the crustal movement when changing from the first stage to the second is

\footnotetext{
*Corresponding author: mfilatev@gmail.com
} 
not taken into account [1]. For this reason, there may be nonconformities between the calculated parameters determined for different stages of stope works performance. To remove the errors of this type, it is recommended [2] to predict the displacement processes using an additional element of the computational scheme - the trajectory of the maximum subsidence of the earth surface points, linking it with the other current parameters of the shift troughs.

In the case of incomplete undermining of the earth surface, according to [1], the maximum subsidence angle $(\theta)$ is determined regardless of the values of complete displacement angles $\left(\psi_{1}, \psi_{2}\right.$ and $\left.\psi_{3}\right)$. By determination according to [1], the complete displacement angles are internal angles relatively to the mined-out space, formed on the vertical sections along the main cross section of the trough by the seam plane and by lines connecting the boundaries of the mine working with the boundaries of the flat bottom of the trough. Until the complete undermining of the earth surface, the flat bottom of the trough is absent, for this reason, for this case, there are no recommendations [1] to determine the angles $\psi_{1}, \psi_{2}$ and $\psi_{3}$. In the computational scheme [3, 4] until the complete undermining, the angles $\psi_{1}, \psi_{2}$ and $\psi_{3}$ in terms of physics are formed by connecting the lines of the mine working boundaries with the points of maximum subsidence of the earth surface $\left(\eta_{m}\right)$. The set of such points corresponds to the trajectory curve (8) of the maximum subsidence of the earth surface (Fig. 1). At each point of maximum subsidence of the earth surface, theoretically, the lines segments characterizing the maximum subsidence angle and complete displacement angles should intersect. As an example (Fig. 1), the position of the point $A_{0}$ corresponding to the beginning of the crustal movement is determined by the angles $\psi_{01}, \psi_{02}$ and $\theta_{0}$ (the angle $\psi_{01}$ is not indicated on the chart).

The point $K$ is determined by the angles $\psi_{1}, \psi_{2}, \theta_{K}$ and its position corresponds to the beginning of the trough flat bottom formation $\left(\eta_{m}=\eta_{0}\right)$. After the trough flat bottom formation, the crustal movement depends only on the stope face advance.

The characteristic points of the curve of subsidence dynamics above the stope face are: $A$ - corresponds to the beginning of the crustal movement; $O$ - is located in the alignment with the stope face and serves as the starting point on the abscissa axis; $B$ - the beginning of the active stage; $C$ - the maximum subsidence rate and the bend point of the curve; $D-$ the end of the active stage and the beginning of the decay stage; $F$ - the beginning of the residual effect of undermining.

The purpose is to establish the correspondence between the angular and linear parameters of the undermined rocks displacement and the crustal movement with their values determined in accordance with the normative document.

On the basis of the surveying observations over the reference points movement on the earth surface and the stope face advance, the empirical curve (8) of the trajectory of the earth surface maximum subsidence is determined from the maximum subsidence points. Having accepted the value $\eta_{m}=0$ in the equation $\eta_{m}=f_{1}\left(L_{p}\right)$, the distance $L_{p}$ is calculated relative to the projection of the fixed wall of the first cut working. It determines the position of the point $A_{0}$ on the earth surface (Fig. 1). According to the experimental data, the removal of the stope face from the face entry $L_{H}$ is also determined, which corresponds to the position of the point $A_{0}$. To do this, $\eta_{m}=0$ is accepted in the equation $\eta_{m}=f_{2}(L)$ and the desired value $L=L_{H}$ is evaluated. Knowing the position of the point $A_{0}$ on the earth surface and the distance $L_{H}$, the angles of complete displacements $\psi_{01}, \psi_{02}$ corresponding to them and the maximum subsidence angle $\theta_{0}$, are graphically determined (Fig. 1).

Similarly, by the current positions of the maximum subsidence points and the corresponding distances from the stope face to the first cut working the subsequent values of the angles of complete displacement and maximum subsidence are determined. 


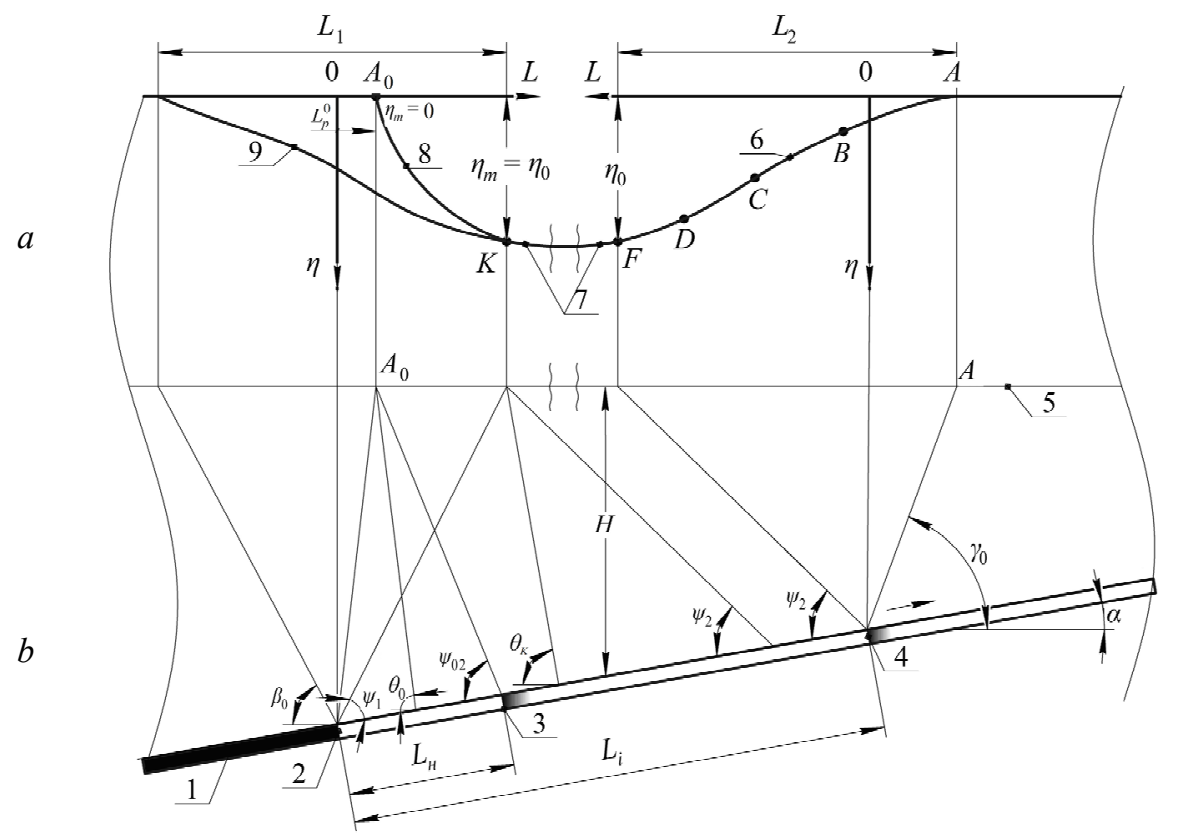

Fig. 1. The scheme of shift troughs formation of the earth surface (a) and its compliance with the stope mine workings parameters (b); 1 - the mined seam; 2 - the first cut working; 3 - the position of the stope face relative to the face entry, at which the crustal movement begins $\left(\eta_{m}=0\right) ; 4-$ the position $i$ of the stope face after a complete undermining of the earth surface (formation of the trough flat bottom); 5 - the earth surface; 6 - the dynamic half-trough above the stope face; 7 - the flat bottom of the shift trough; 8 - the trajectory of the maximum subsidence points of the earth surface; 9 - the stationary half-trough from the side of the face entry; $\beta_{0}, \gamma_{0}$ - the boundary angles, from the side of the seam gradient and the seam rise, respectively; $\psi_{1}, \psi_{2}-$ the angles of complete displacements, from the side of the seam gradient and the seam rise, respectively; $\psi_{02}$ - the angle of complete displacements, corresponding to the beginning of the crustal movement when removing the stope face from the first cut working at a distance of $L_{H} ; \theta_{0}, \theta_{K}$ - the angles of maximum subsidence, when reaching the earth surface rocks $(\eta=0)$ by the displacement processes and the flat bottom formation $\left(\eta_{m}=\eta_{0}\right)$, respectively; $H$ - the average depth of conducting the stope works; $\alpha$ - the incidence angle of the seam; $\eta, \eta_{m}$ - the subsidence and the maximum subsidence of the earth surface, respectively; $\eta_{0}$ - the depth of the trough flat bottom; $A_{0}, A$ - the points of crustal movement beginning when removing the stope face from the face entry and ahead of it, respectively; $B, C, D$, $F$ - the characteristic displacement points under the influence of the stope face advance; $\longrightarrow-$ the direction of stope face advance.

The chart (Fig. 1), shows an example of determining the angular parameters for the end point $K$. It characterizes the end of the first stage of the shift trough formation on the earth surface and indicates the change to the second stage. At the second stage, the crustal movement is characterized by a half-trough (6), which is determined on the basis of surveying observations. The characteristic points $(A, B, C, D, F)$ are calculated for this curve. The position of points $A$ and $F$ on the earth surface is determined by the boundary angle $\left(\gamma_{0}\right)$ and the angle $\psi_{2}$ of complete displacements, respectively (Fig. 1).

When having available experimentally determined curves $(6,8,9)$, which characterize the earth surface displacement shift trough and parameters of stope works development, it is possible to compare them with the recommended values according to the normative document [1] for the entire period of the extraction site operation at the two stages of shift troughs formation. 


\section{The research results}

To achieve this purpose, the results of surveying observations conducted in different miningand-geological and mining conditions have been involved into consideration. Most of the known experiments were carried out in the Western Donbas mines (Ukraine). In particular, the changes in the parameters of the stope mine workings and the crustal movements in the conditions of the "Stepova" Mine have been studied quite thoroughly [5]. For this object, almost all the parameter values necessary for the implementation of the computational scheme have been determined experimentally (Fig. 1). Statistical analysis of the initial experimental data [5] has shown that the trajectory curve of the maximum subsidence of the earth surface points $\left(\eta_{m}\right)$ can be most accurately described by the exponential dependence:

$$
\eta_{m}=a-b \cdot \exp \left(c \cdot L_{p}\right), \mathrm{mm},
$$

where $a, b, c$ are the empirical coefficients for the studied object.

Similarly, the value $\eta_{m}$ changes when the stope face $(L)$ is removed from the face entry:

$$
\eta_{m}=a_{1}-b_{1} \cdot \exp \left(c_{1} \cdot L\right), \mathrm{mm} .
$$

Empirical coefficients of equations $(1,2) a=853, b=1273, c=-0.1$ and $a_{1}=853$, $b_{1}=1550, c_{1}=0.026$ have been obtained on the basis of experimental data processing (Table 1).

Table 1. Experimental values of the parameters $L_{p}, L, \eta_{m}$ in the conditions of the "Stepova" Mine

\begin{tabular}{|c|c|c|c|c|c|c|c|}
\hline \multirow{2}{*}{ No. } & \multirow{2}{*}{$\begin{array}{l}\text { The position of } \\
\text { the stope face } \\
\text { and the } \\
\text { corresponding } \\
\text { number of the } \\
\text { shift trough }\end{array}$} & \multirow{2}{*}{$\begin{array}{l}\text { The distance from } \\
\text { the point of } \\
\text { maximum } \\
\text { subsidence to the } \\
\text { projection of the } \\
\text { face entry, } L_{p}, \mathrm{~m}\end{array}$} & \multirow{2}{*}{$\begin{array}{l}\text { The distance } \\
\text { between the } \\
\text { stope face and } \\
\text { the first cut } \\
\text { working t, } L, \\
\mathrm{~m}\end{array}$} & \multirow{2}{*}{$\begin{array}{c}\text { The } \\
\text { maximum } \\
\text { subsidence } \\
\text { of the earth } \\
\text { surface, } \eta_{m} \text {, } \\
\text { mm }\end{array}$} & \multirow{2}{*}{$\begin{array}{l}\text { The angle of } \\
\text { maximum } \\
\text { subsidence } \\
\text { of the earth } \\
\text { surface, } \theta \text {, } \\
\text { degree }\end{array}$} & \multicolumn{2}{|c|}{$\begin{array}{c}\text { Angles of } \\
\text { complete } \\
\text { displacements }\end{array}$} \\
\hline & & & & & & $\begin{array}{c}\psi_{1}, \\
\text { degree }\end{array}$ & $\begin{array}{c}\psi_{2}, \\
\text { degree }\end{array}$ \\
\hline 1 & $-^{*}$ & 4 & 23 & 0 & 84 & 97 & 93 \\
\hline 2 & 3 & 0 & 27 & 64 & 83 & 90 & 81 \\
\hline 3 & 4 & 6 & 41 & 255 & 83 & 83 & 77 \\
\hline 4 & 5 & 14 & 58 & 478 & 83 & 79 & 73 \\
\hline 5 & 7 & 24 & 83 & 693 & 82 & 74 & 66 \\
\hline 6 & 8 & 31 & 97 & 740 & 82 & 71 & 63 \\
\hline 7 & 9 & 41 & 116 & 780 & 82 & 66 & 59 \\
\hline 8 & 11 & 50 & 130 & 812 & 82 & 62 & 58 \\
\hline 9 & 16 & 46 & 145 & 820 & 76 & 64 & 52 \\
\hline 10 & 23 & 53 & 156 & 828 & 78 & 62 & 55 \\
\hline 11 & 34 & 54 & 181 & 836 & 72 & 62 & 49 \\
\hline 12 & 37 & 55 & 188 & 836 & 70 & 61 & 42 \\
\hline 13 & 38 & 55 & 208 & 844 & 66 & 61 & 38 \\
\hline 14 & 40 & 59 & 219 & 852 & 65 & 59 & 37 \\
\hline 15 & 41 & 64 & 231 & 852 & 64 & 57 & 35 \\
\hline 16 & 42 & 66 & 259 & 852 & 58 & 56 & 30 \\
\hline 17 & 43 & 69 & 286 & 868 & 54 & 55 & 28 \\
\hline
\end{tabular}
according to [4] and their corresponding angles $\theta, \psi_{1}$ and $\psi_{2}$.

*Note: parameters $L_{p}=4 \mathrm{~m}$ and $L=23$ are determined from the condition $\eta_{m}=0$ according to equations 1 and 2 .

The position of the point $A_{0}$ on the earth surface (Fig. 1) has been determined from the condition $\eta_{m}=0$ :

$$
L_{p}^{0}=\frac{\ln (a / b)}{c}=\frac{\ln (853 / 1273)}{0.10}=4 \mathrm{~m} .
$$


The parameter $L_{H}$ is determined at $\eta_{m}=0$ according to the equation 2:

$$
L_{H}=\frac{\ln \left(a_{1} / b_{1}\right)}{c_{1}}=\frac{\ln (853 / 1550)}{0.026}=23 \mathrm{~m} .
$$

The experimentally determined parameters of the shift trough are shown in the graph (Fig. 2a), and the corresponding dimensions of the stope mine workings are shown in Fig. 2b.

$a$

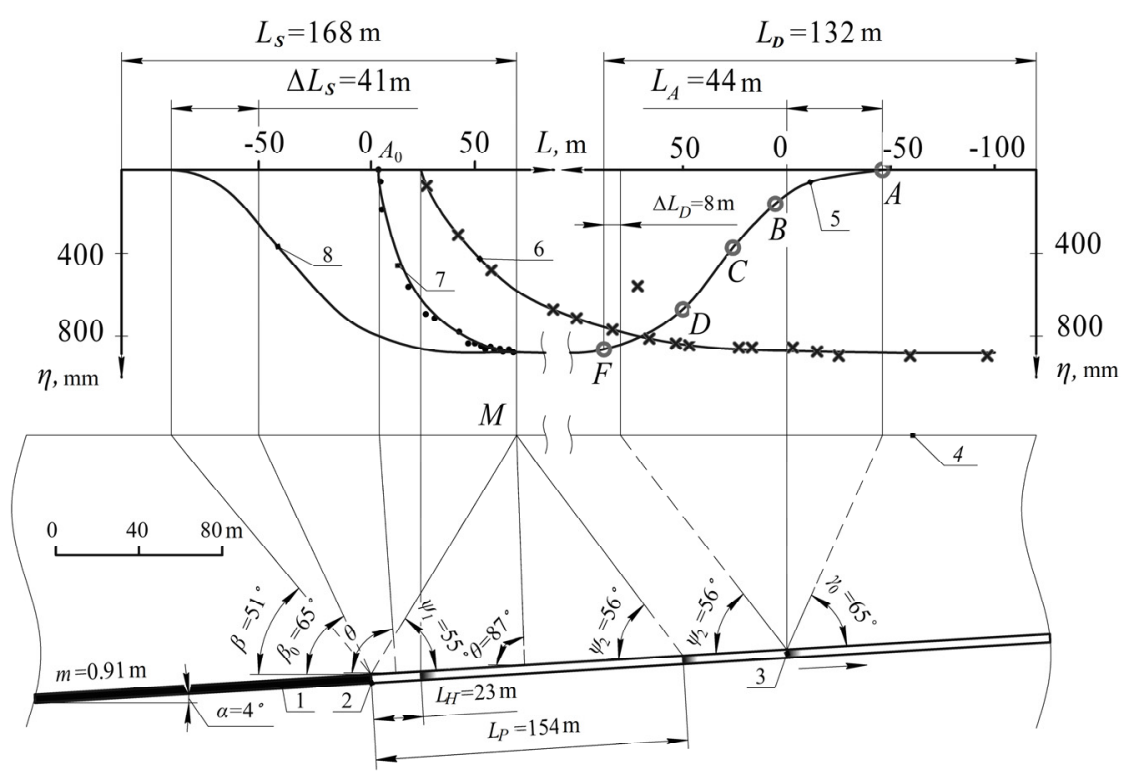

Fig. 2. The results of experimental observations of the crustal movement during its undermining in the conditions of the "Stepova" Mine [5] (a) and the corresponding characteristic dimensions of the stope mine working and angular parameters of rocks displacement (b); 1 - the mined seam; 2 - the stationary face of the face entry; 3 - the position of the stope face after the flat bottom formation; 4 the earth surface; 5 - the curve of the dynamic half-trough above the stope face according to the results of the averaged experimental data of reference points $25,30,35,40$ and 45 subsidence [5]; 6 the curve of maximum subsidence of the earth surface points depending on the distance between the first cut working and the stope face $\left(\eta_{m}=f_{2}(L) ; 7\right.$ - the curve of maximum subsidence of the earth surface points depending on the distance to the face entry projection $\left(\eta_{m}=f_{1}\left(L_{p}\right)\right) ; 8$ - the stationary half-trough according to the experimental data [5]; $m$ - the thickness of the mined seam; $\alpha$ - the incidence angle of the seam; $\beta$ - the boundary angle determined from the dimension of stationary half-trough; $\beta_{0}, \gamma_{0}$ - the boundary angles in accordance with the recommendations [1]; $\psi_{1}, \psi_{1}-$ the angles of complete displacements [1]; $\theta$ - the angle of maximum subsidence of the earth surface [1]; $L_{S}, L_{D}$ - the lengths of the stationary and dynamic half-troughs, respectively; $-\Delta L_{S}, \Delta L_{D}$, - the divergence of results in determining the dimensions of half-troughs according to the surveying observations on the earth surface and in the angles, as recommended [1]; $A, B, C, D, F$ - the characteristic points of the dynamic half-trough above the stope face; $\cdot, \times-$ the experimental data; $\longrightarrow-$ the direction of the stope face advance.

Their comparison shows the correspondence in most cases of the recommended displacement angles [5] to the parameters of the troughs. The angle of the maximum subsidence of the earth surface $\left(\theta=87^{\circ}\right)$ has determined quite accurately the position of the point of the crustal movement beginning. At the time of the trough flat bottom formation, when removing the stope face from the face entry by $154 \mathrm{~m}$, the straight line segments 
which characterize the complete displacement angles $\left(\psi_{1}=55^{\circ}\right.$ and $\left.\psi_{2}=56^{\circ}\right)$ and the angle of maximum subsidence of the earth surface $\left(\theta=87^{\circ}\right)$, have intersected approximately, in one point $(M)$. Point $M$ (Fig. 2) corresponds to the beginning the flat bottom formation of the earth surface shift trough and the change to the second stage of its formation. For this reason, further analysis involved data on the reference points $25,30,35,40$ and 45 subsidence (Fig. 3). The results of these observations were systematized, taking as the origin of coordinates the moment of intersection by the stope face of the vertical line drawn through the point (reference point) of the observation (Fig. 4).

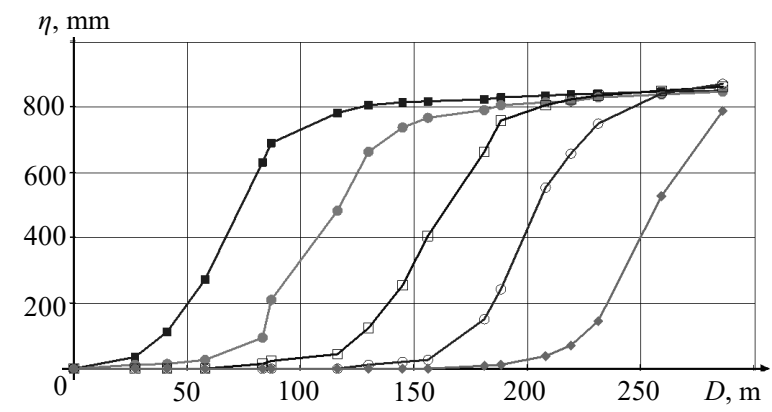

Fig. 3. The subsidence of reference points $(\eta)$ on the earth surface with removal $(L)$ of the stope face from the face entry in "Stepova" Mine [5]: $\mathbf{\bullet}, \bullet, \square, \circ,-$ the experimental data of reference points $25,30,35,40$ and 45 subsidence, respectively.

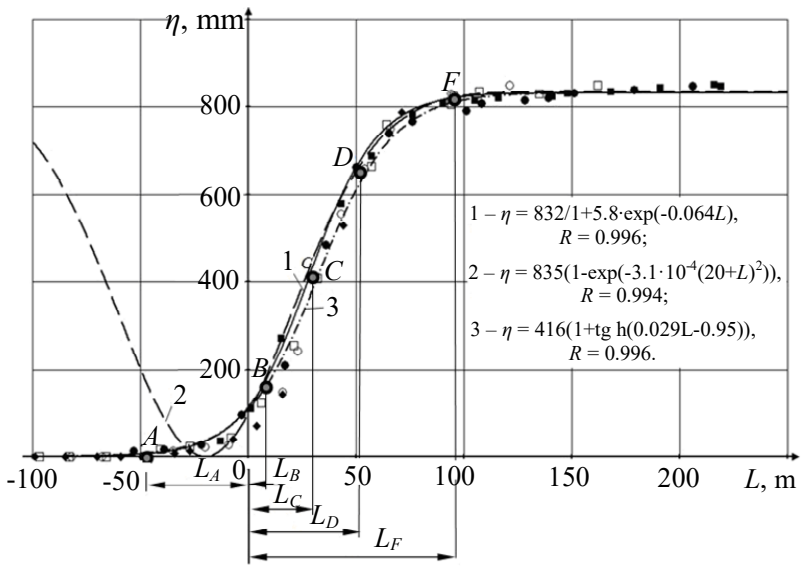

Fig. 4. The subsidence $(\eta)$ of the earth surface points during the stope works performance in "Stepova" Mine with respect to the projection position of the stope face (L) according to [5]: 1, 2, 3the approximating curves corresponding to the logistic, the exponential dependences and the function of hyperbolic tangent; $A, B, C, D, F$ - the characteristic points of the curve of the subsidence dynamics of the earth surface according to the logistic equation; $L$ - the distance from the point (reference point) of observation to the line projection of the stope face; $R$ - the correlation ratio; $\mathbf{\square}, \bullet$, $\square, \diamond,-$ the experimental data of reference points subsidence, respectively, 25, 30, 35, 40 and 45 .

It is known $[3,4,6,7]$, that the curve of the subsidence $(\eta)$ of the earth surface points under the influence of the stope face advance can be described by logistic, exponential or hyperbolic tangent dependences. The processing of experimental data for determining the empirical coefficients of these equations, has been performed by the method of least squares (Table 2). Using their numerical values, we have found the boundaries of the stages of the earth surface subsidence (positions of points $A, B, C, D, F$ ). The points $A$ and $F$ 
characterize the dimensions of the dynamic half-trough $\left(L_{D}=32 \mathrm{~m}\right)$ above the stope face (Fig. 2). The boundary angle $\gamma_{0}=65^{\circ}[1]$ completely corresponds to the position of point A, and the position of point $\mathrm{F}$ determines accurately the complete displacements angle $\left(\psi_{2}=56^{\circ}\right)$. The difference in the determination of the dynamic half-trough boundary $\left(\Delta L_{D}\right)$ does not exceed $8 \mathrm{~m}$, which accounted for approximately $6 \%$ deviation.

Table 2. The results of determining the coordinates of the characteristic points of the earth surface subsidence [5] in its undermining by the "Stepova" Mine.

\begin{tabular}{|c|c|c|c|c|c|c|}
\hline \multirow{3}{*}{$\begin{array}{l}\text { The results of } \\
\text { processing } \\
\text { and the } \\
\text { characteristic } \\
\text { points (Fig. 4) }\end{array}$} & \multicolumn{6}{|c|}{ Mathematical functions } \\
\hline & \multicolumn{2}{|c|}{ Logistic dependence } & \multicolumn{2}{|c|}{ Exponential dependence } & \multicolumn{2}{|c|}{ Hyperbolic tangent } \\
\hline & \multicolumn{2}{|c|}{$\eta=\frac{a}{1+b \cdot \exp (-c \cdot L)}$} & \multicolumn{2}{|c|}{$\eta=\eta_{\kappa}\left(1-\exp \left[-\beta_{2}\left(L+L_{0}\right)^{2}\right]\right)$} & \multicolumn{2}{|c|}{$\eta=n_{1}\left[1+\tanh \left(n_{2} L+n_{3}\right)\right]$} \\
\hline $\begin{array}{c}\text { Correlation } \\
\text { ratio }\end{array}$ & \multicolumn{2}{|c|}{0.996} & \multicolumn{2}{|c|}{0.994} & \multicolumn{2}{|c|}{0.986} \\
\hline $\begin{array}{l}\text { Empirical } \\
\text { coefficients }\end{array}$ & \multicolumn{2}{|c|}{$\begin{array}{c}a=\eta_{K}=832 ; b=5.8 ; \\
c=0.064\end{array}$} & \multicolumn{2}{|c|}{$\begin{array}{c}\beta_{2}=3.1 \cdot 10^{-4} ; L_{0}=L_{H}=-20 ; \\
\eta_{K}=835\end{array}$} & \multicolumn{2}{|c|}{$\begin{array}{c}n_{1}=416=0.5 \eta_{K} ; \\
n_{2}=0.029 ; n_{3}=-0.95\end{array}$} \\
\hline$A$ & $L_{A}=L_{H}=-44 \mathrm{~m}$ & $\eta_{A}=0 \mathrm{~mm}$ & $L_{A}=L_{H}=-20 \mathrm{~m}$ & $\eta_{A}=0 \mathrm{~mm}$ & $L_{A}=L_{H}=-46 \mathrm{~m}$ & $\eta_{A}=0 \mathrm{~mm}$ \\
\hline$O$ & $L_{o}=0 \mathrm{~m}$ & $\eta_{o}=122 \mathrm{~mm}$ & $L_{o}=0 \mathrm{~m}$ & $\eta_{o}=97 \mathrm{~mm}$ & $L_{o}=0 \mathrm{~m}$ & $\eta_{o}=108 \mathrm{~mm}$ \\
\hline$B$ & $L_{B}=7 \mathrm{~m}$ & $\eta_{B}=175 \mathrm{~mm}$ & $L_{B}=10 \mathrm{~m}$ & $\eta_{B}=201 \mathrm{~mm}$ & $L_{B}=10 \mathrm{~m}$ & $\eta_{B}=175 \mathrm{~mm}$ \\
\hline$C$ & $L_{c}=27 \mathrm{~m}$ & $\eta_{C}=416 \mathrm{~mm}$ & $L_{c}=20 \mathrm{~m}$ & $\eta_{C}=328 \mathrm{~mm}$ & $L_{c}=33 \mathrm{~m}$ & $\eta_{C}=416 \mathrm{~mm}$ \\
\hline$D$ & $L_{D}=48 \mathrm{~m}$ & $\eta_{D}=657 \mathrm{~mm}$ & $L_{D}=50 \mathrm{~m}$ & $\eta_{D}=649 \mathrm{~mm}$ & $L_{D}=55 \mathrm{~m}$ & $\eta_{D}=665 \mathrm{~mm}$ \\
\hline$F$ & $L_{F}=L_{K}=88 \mathrm{~m}$ & $\eta_{F}=815 \mathrm{~mm}$ & $L_{F}=L_{K}=112 \mathrm{~m}$ & $\eta_{F}=818 \mathrm{~mm}$ & $L_{F}=L_{K}=100 \mathrm{~m}$ & $\eta_{F}=815 \mathrm{~mm}$ \\
\hline
\end{tabular}

The maximum deviations (up to $30 \%$ ) have been obtained between the values of the boundary angles from the side of the seam gradient. According to recommendations [1], $\beta_{0}=65^{\circ}$ and according to experimental data [5], $\beta_{0}=51^{\circ}$. Such a divergence led to a difference in the determination of the stationary half-trough $\Delta L_{C}=41 \mathrm{~m}$.

The experimental data [5] made it possible to estimate changes in the angle of complete displacements $\left(\psi_{1}\right)$ from the side of the first cut working when removing $(L)$ the stope face. After the square of mined-out space has formed with the side equal to the length of the longwall $L_{l}=150 \mathrm{~m}$, the angle $\psi_{1}$ changed slightly in the range of $55-62^{\circ}$ (Table 1 ), which corresponds to the recommendations [1]. The angle of complete displacements $\left(\psi_{2}\right)$ from the side of the stope face, after the formation of the square of mined-out space, continued to decrease to $28^{\circ}$ (see Table 1 ).

This caused doubts about the reality of such a change, since the values of $L_{p}$ and angle $\psi_{1}$ remained almost constant. This is explained by the fact that the value of complete displacements angle $\psi_{2} \approx 55^{\circ}$ was formed after the formation of the square of mined-out space, and the stope face advance did not influence its further formation. This is confirmed by insignificant earth surface subsidence during this period (from 828 to $868 \mathrm{~mm}$ ), which were possible with the rocks compaction. The total subsidence during this period was less than $5 \%$ of the maximum for the entire period of the extraction site operation. Such subsidence could not cause a change in the angles of complete displacements, and the results indirectly confirm the scientific position [8] on the constancy of the rocks displacement zone with discontinuity after the formation of the square of the mined-out space.

As the second object for consideration, the facilities have been chosen for the anthracite layer $K_{5}^{\prime}$ mining by P.L. Voikova Mine (SE "Sverdlovantratsyt", Ukraine) [9, 10]. The choice of these facilities is conditioned by the significant differences in their mining and geological conditions if compared to the conditions of the stope works performance by "Stepova" Mine. These differences were in the conducting the stope works at a depth of about $700 \mathrm{~m}$ and in the more coherent rocks enclosing anthracite seams. This approach makes it possible to establish differences in the formation of the earth surface shift troughs parameters. 


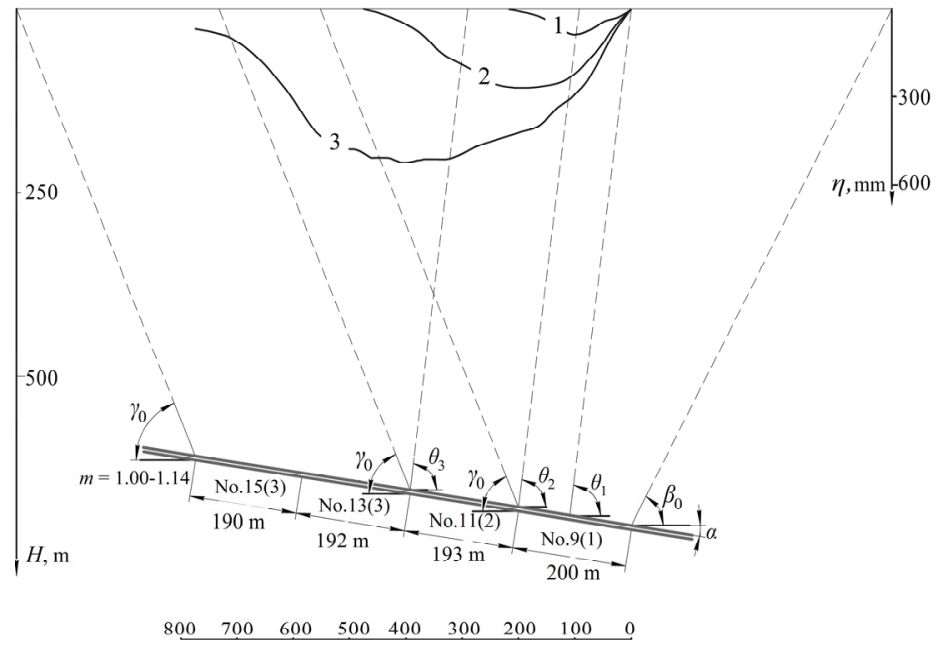

Fig. 5. The graphs of the earth surface subsidence after mining the extraction pillars by P.L. Voikova Mine according to [9]: No.9(1), No.11(2), No.13(3), No.15(3) - the numbers of the longwalls, the order of their mining and the troughs of the earth surface displacement corresponding to them; $m-$ the seam thickness, $\mathrm{m} ; H$ - the depth of the stope works performance, $\mathrm{m} ; \alpha=9^{\circ}-$ the angle of the seam gradient; $\eta$ - the earth surface subsidence, $\mathrm{mm} ; \beta_{0}=63^{\circ}$ - the boundary angle on the seam gradient; $\gamma_{0}^{1}=\gamma_{0}^{2}=\gamma_{0}^{3}=68^{\circ}-$ the boundary angles on the seam rise and their location after mining the longwalls No.9, No.11 and double longwalls No.13 and No.15, respectively; $\theta_{1}=\theta_{2}=\theta_{3}=83^{\circ}-$ the angles of maximum rocks subsidence and their location after mining the longwalls No.9, No.11 and double longwalls No.13, No.15, respectively.

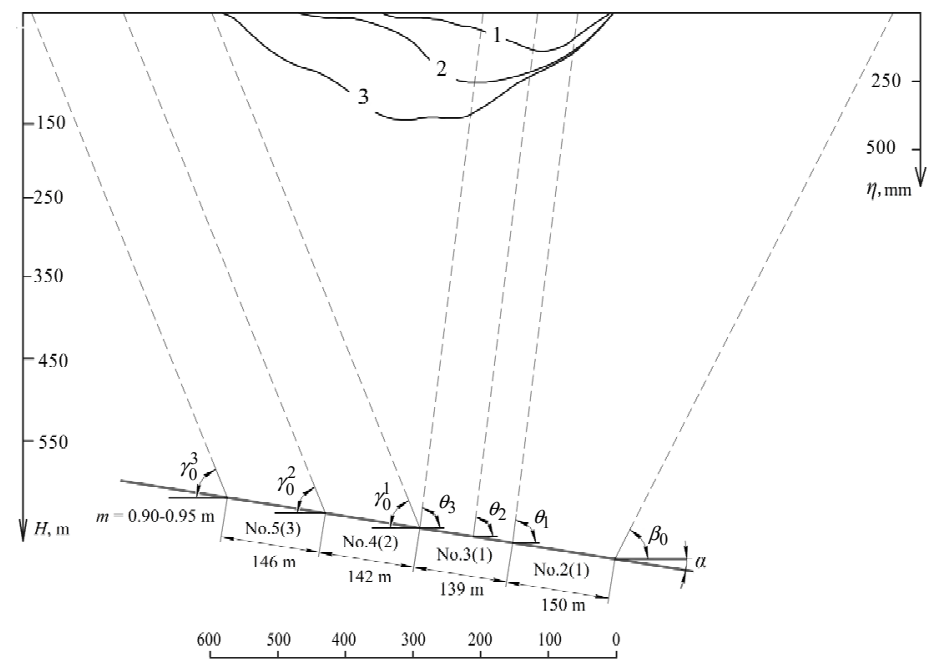

Fig. 6. The graphs of the earth surface subsidence after mining the extraction pillars by P.L. Voikova Mine according to [9]: No.2(1), No.3(1), No.4(2), No.5(3) - numbers of the longwalls, the order of their mining and the troughs of the earth surface displacement corresponding to them; $m$ - the seam thickness, $\mathrm{m} ; H$ - the depth of the stope works performance, $\mathrm{m} ; \alpha=9^{\circ}-$ the angle of the seam gradient; $\eta$ - the earth surface subsidence, $\mathrm{mm} ; \beta_{0}=63^{\circ}$ - the boundary angle on the seam gradient; $\gamma_{0}^{1}=\gamma_{0}^{2}=\gamma_{0}^{3}=68^{\circ}-$ the boundary angles on the seam rise and their location after mining the double longwalls No.2, No.3 and single longwalls No.4 and No.55; $\theta_{1}=\theta_{2}=\theta_{3}=83^{\circ}-$ the angles of maximum rocks subsidence and their location after mining the double longwalls No.2, No.3 and longwalls No.4, No.5, respectively. 
On the anthracite seam $K_{5}^{\prime}$, two groups of extraction sites have been mined, with four longwalls in each group [9, 10]. In the first group, two single longwalls of 200 and $190 \mathrm{~m}$ in length have been mined consistently, and then two more double longwalls with a total length of $382 \mathrm{~m}$. Based on the results of such type of mining, the parameters of the shift troughs for the mined out space of 200, 393 and $775 \mathrm{~m}$ width, have been established (Fig. 5). In the second group, the seam has been mined, at first, by two double longwalls with a total length of $289 \mathrm{~m}$. Then, two more longwalls with length of 142 and $146 \mathrm{~m}$ have been mined consistently. For the longwalls of the second group the parameters of three shift troughs of the earth surface for the mined-out out space with width 289, 431 and $577 \mathrm{~m}$, respectively, have been experimentally determined (Fig. 6).

An example of the anthracite seam mining has shown that the method [1] of geometrical determination of the angular and linear parameters of shift troughs of the earth surface does not correspond to the experimental data. This indicates the need for additional surveying observations when mining the anthracite seams.

\section{Conclusions}

The developed scheme for the formation of shift troughs of the earth surface made it possible to combine the displacement parameters of two stages.

In the conditions of the Western Donbas (Ukraine), angular and linear parameters of the undermined rocks displacement and the crustal movement in most cases correspond to the recommendations of the normative document. The significant differences were obtained only in the determination of the boundary angles from the side of the face entry.

When mining the anthracite seams, the angular and linear parameters of the undermined rocks displacement and the crustal movement do not comply with the recommendations of the normative document. This situation indicates the need for additional studies using the parameters of the earth surface shift troughs, including the use of the curve of maximum subsidence of the points.

This work was conducted within the project "Development of the forecasting and control system for the dynamics of methane content in mine workings" (State registration No. 0114U004419).

\section{References}

1. GSTU 101.00159226.001-2003. (2004). Pravyla pidrobky budivel i pryrodnykh obiektiv pry vydobuvanni vuhillia pidzemnym sposobom. Kyiv: Ministerstvo palyva ta enerhetyky Ukrainy.

2. Filat'ev, M.V., Antoshchenko, N.I., \& Pyzhov, S.V. (2016). Formirovanie dinamicheskoy i statsionarnoy polumul'd sdvizheniya zemnoy poverkhnosti pro otrabotke ugol'nykh plastov. Zbirnyk naukovykh prats Donbaskoho derzhavnoho tekhnichnyoho universitetu, 1(45), 15-24.

3. Dubovik, A.I., Filat'ev M.V., \& Filat'eva, E.N. (2017). Inzhenernaya geomekhanika pri otrabotke ugol'nykh plastov. Lysychansk: Donbaskyi derzhavnyi tekhnichnyi universitet.

4. Filatiev, M., \& Laguta, A. (2017). Experimental determination of angle values of the rocks full displacement when undermining them by breakage headings. Mining of Mineral Deposits, 11(4), 111-116. https://doi.org/10.15407/mining11.04.111

5. Larchenko, V.G. (1998). Vliyanie podzemnoy razrabotki ugol'nykh plastov na sostoyanie zemnoy poverkhnosti. Vestnik Mezhdunarodnoy akademii nauk ekologii i bezopasnosti, 4(12), 39-41.

6. Filatiev, M. (2017). Determination of cross-correlation dependences between the parameters of swallies of the earth surface and the movement of underworked rocks. Naukovyi Visnyk Natsionalnoho Hirnychoho Universytetu, (3), 43-48. 
7. Filatiev, M. (2017). Analytical determination of co-ordinates of characteristic points of settling of earthly surface above a cleansing coalface. Naukovyi Visnyk Natsionalnoho Hirnychoho Universytetu, (1), 33-37.

8. Lobkov, M.I. (2012). Rozvytok naukovykh osnov prohnozu obvalennia porid pokrivli pry vyimanni lavoiu polohoho plasta. Ph.D. Instytut fizyky hirnychykh protsesiv.

9. Borzykh, A.F., Gorovoy, Ye.P. (1999). Vliyanie shiriny vyrabotannogo prostranstva na aktivizatsiyu sdvizheniya uglenosnogo massiva. Ugol' Ukrainy, (9), 26-30.

10. Filatiev, M. (2017). Effect of rocks displacement activation on the formation of the surface trough during anthracite seams extraction. Mining of Mineral Deposits, 11(2), 91-95. https://doi.org/10.15407/mining11.02.091 